\title{
EXCAVATING LEGAL LANDSCAPES: Juridical Archaeology and the Politics of Bureaucratic Materiality in Bogotá, Colombia
}

\author{
FEDERICO PÉREZ \\ Portland State University \\ (D) http: / / orcid.org/0000-0003-0850-6092
}

An intricate patchwork of urban laws lies at the core of Bogotá's seemingly haphazard built environment and its conflicts over urban development. This was made clear to me during a public meeting about the city's "excessive regulatory density" organized by the Planning Department in 2010 as part of its efforts to modify Bogotás master plan. A typical exercise in participatory planning, the underattended meeting was more bureaucratic ritual than meaningful political exchange. A seasoned bureaucrat-turned-consultant launched the discussion by recounting his everyday dealings with urban laws: "Someone recently requested my expert opinion about a plot with a building permit from the 1950s. I said, 'It must be regulated by [decree] 185 of 1951, when Don Corbi [Le Corbusier] came [to Bogotá] and created the city's famous pilot plan.' But then, looking further into the matter, I found very interesting things." The expert went on to describe the city's profound regulatory confusion and, as he put it, the "archaeological" skills necessary to interpret this layered terrain.

The complexity of urban laws is partly the result of [a technical concept] that refers current regulations back to older urban laws, with all the transformations and modifications they accumulated through time. This makes the interpretation of the law an intricate archaeological exercise. And so you find really incredible things in regulations from the 1940s and 1950s. 
But because not everyone can master this archaeological practice, the application of the law loses all transparency.

For him, urban laws constituted a nearly indecipherable amalgam of regulatory layers. In this article I explore the interpretative practices associated with these complex legal formations, which experts and bureaucrats in Bogotá call "juridical archaeology" (arqueología jurídica). By employing the archaeological metaphor in their work, planners conjure images of a layered and murky legal topography. They endow urban laws with the materiality and temporal sedimentation of geological strata. While such idioms are typically couched as criticisms of Bogotá's legal confusions, I argue that juridical archaeology is best understood as a form of strategic reification. By evoking a formation that is unknowablean impenetrable terrain waiting to be excavated - legal operators obfuscate the politics of juridical interpretation. In their view, the accretion of urban codes has created a treacherous and unstable terrain, a system run amok. But fetishizing legal technicalities as the main culprits of urban disorder ultimately becomes an integral part of bureaucrats' and experts' deft manipulations of the law and claims to authority. It is a key strategy they employ to displace individual responsibility and minimize contingency as they sift through decrees and piece together regulatory frameworks for the city's development.

Anthropologists have become increasingly attentive to the everyday pragmatics of bureaucracy. Rather than representing the state primarily as a discursive site, recent ethnographies have focused on the situated practices and performative dimensions of bureaucracies (Feldman 2008; Gupta 2012; Hetherington 2011; Hull 2012b; Mathews 2011). In this context, scholars have called for the study of documents, files, and artifacts as key mediators of bureaucratic action (Hull 2012a). In his recent ethnography of urban planning in Islamabad, for instance, Matthew Hull (2012b, 13) sets out to "analytically restore the visibility of documents, to look at rather than through them." For Hull this entails recognizing the ways in which the materiality and aesthetics of bureaucratic artifacts mediate discourse and action. Things matter from this perspective, and not simply as instruments or repositories of knowledge. The material qualities of documents, their circulations and inscriptions, actively shape governmental practice by projecting authority, diffusing individual responsibility, and enabling the formation of coalitions around them. In a related argument, Annelise Riles $(2005,973)$ calls for a move beyond "culturalist" studies that treat the law as "the repository of social meanings." Instead, she insists on the need to study legal technicalities in 
their own right. At stake for her is "the agency of technocratic legal form" (Riles 2005, 980), that is, the idea that technicalities, like documents, are agents mediating social practice.

In Bogotá, officials and experts employ juridical archaeology to parse the technicalities that have shaped the city's legal regime through time. Juridical archaeology appears as a technique to navigate the city's opaque bureaucratic infrastructures and search for older and more authoritative regulatory artifacts. The archaeological metaphor proves particularly significant in this regard. It evokes a tangible field in which urban regulations appear as objective facts on the ground. Furthermore, the idiom of archaeology endows legal artifacts with the power of tradition by portraying them as historic relics. This usage is especially resonant in Colombia, where archaeological and geological knowledge since the nineteenth century has proven integral to the production of mythical pasts and narratives of nationhood (Appelbaum 2013).

Rather than taking the discourse of juridical archaeology at face value, I argue that bureaucrats and experts working within Bogotá's planning regimes further their interests precisely by appealing to the agency and obduracy of legal infrastructures. They employ juridical archaeology as a tactical instrument to mobilize legal resources to a variety of ends. ${ }^{1}$ The image of an excessive and intricate legal topography becomes a necessary illusion, a fabrication integral to the workings of power. By focusing on these rhetorical ploys, I do not imply that the physicality and aesthetics of state artifacts are irrelevant, but rather caution against overemphasizing their agency as the protagonists of bureaucratic action. The mediating role of bureaucratic artifacts - their performance of legal and administrative maneuvers - is inextricably bound to the ways in which experts locate such legal instruments within a recalcitrant archaeological landscape.

In what follows I consider how different actors - from bureaucrats to realestate lawyers - claim authority, deflect responsibility, and justify stratagems by portraying a capricious legal landscape. While Hull and Riles maintain that technical artifacts are effective agents in bureaucratic processes, I intend to show that such ideas can become part of a rhetoric that actors mobilize deliberately and strategically. In this sense, my analysis suggests that scholarship on bureaucratic materiality and technicalities risks blurring the distinction between agency and reification by overlooking the ways in which social actors themselves mobilize discourses about the power of objects. In Bogotá, experts underplay their maneuvers by treating legal instruments as autonomous artifacts with agentive qualities. In this sense, viewing bureaucracies as assemblages that take on a life of 
their own not only occludes operators' practices but also prevents us from grasping actors' own strategic attempts to portray bureaucracy as an unruly system. ${ }^{2}$

To shed light on such modes of bureaucratic reification and on the legal manipulations they obscure, I draw on the vast literature on state and legal fetishism (Abrams 1988; Coronil 1997; Taussig 1992; Tomlins and Comaroff 2011). Several authors have argued that the idea of the state as a coherent object is constituted in everyday practice. In his recent ethnography on bureaucracy in rural India, Akhil Gupta $(2012$, 54) goes further and shows that state reification constitutes not only a scholarly problem but also a political issue. Representing the state as a unified apparatus is an "important means of rule" through which powerful actors naturalize their interests and shield themselves from critique.

By calling attention to ways in which experts give form to a composite landscape of legal artifacts, I expand on conceptualizations of state reification in several ways. I show that the social construction of state authority operates at various scales, with experts and citizens reifying urban law as a distinctive embodiment of stateness. ${ }^{3}$ My analysis also joins other scholarship that has attempted to rehabilitate the critical power of reification (Graeber 2005; Silva 2013) beyond notions of false consciousness and mystification. Reification is a contested practice - a form of social creativity - that is socially and politically productive. Far from a firmly held belief, reification emerges here as a practice through which legal forms and artifacts are invested with power and made into fetishes that animate social life. ${ }^{4}$ The practice of juridical archaeology shows that processes of reification are never entirely successful. In Bogotá, sociopolitical conflicts constantly reemerge through cracks in the city's legal and bureaucratic regime. By studying these processes ethnographically, I show how the artifactual agency of Bogotá's legal landscapes and documents recedes in practice, revealing the operators and maneuvers that lie behind them. Ultimately, I argue that state reification is not necessarily restricted to ideas of unity and coherence. The trope of juridical archaeology shows that disorder itself can be reified as a concrete amalgamation of incompatible parts and pieces. In these terms, I explore the materialization of bureaucratic complexity and confusion in social practice. ${ }^{5}$

Juridical archaeology also has significant implications in current debates about urban governance. In her discussion of urban development in India, Ananya Roy $(2009,83)$ rejects narratives about "the failure of planning or the absence of the state." She calls attention instead to deeply ambiguous legal regimes where exceptions constitute key strategies of power (see also Ghertner 2011; Valverde 2012). In Bogotá the ability to define the boundary between legality and illegality 
also marks a crucial source of power. However, the focus on legal exceptionalism does not capture the specific configurations of everyday legal and political maneuvering in the city. In contrast, my analysis calls attention to a particular history and cultural politics of bureaucratic practice in which excess figures more prominently. Resonating closely with what James Holston (1991) describes as the strategic use of legal complication in urban Brazil, bureaucratic excess is a phenomenon that has deep roots in Latin America. Power and authority, in this specific genealogy, are associated with exaggeration and artifice. I aim to show that the act of representing bureaucratic labor as the stratigraphic excavation of intricate juridical fields is integral to the staging of bureaucratic power.

Finally, my analysis speaks to the expanding anthropology of infrastructure. From water pipes to oil rigs, anthropologists have become increasingly interested in infrastructural worlds (Anand 2011; Appel 2012). While this literature has been particularly attentive to the techno-material articulation of political processes and networks, it has proven less attuned to the symbolic and performative dimensions of infrastructural systems. This is what Brian Larkin (2013, 329) calls the poetics of infrastructure: the semiotic and aesthetic dimensions of infrastructures that can take on "fetish-like aspects that sometimes can be wholly autonomous from their technical function.” As I argue below, the practice of juridical archaeology points to a form of "infrastructural fetishism" (Larkin 2013, 333) in which paperwork and bureaucratic artifacts take on an aura of inscrutability that is integral to their political effects (cf. Gupta 2012, 208). Rather than remaining in the background as invisible layers of control (Star 2002), Bogotá's bureaucratic infrastructures become vehicles of power in large part through their appearance as muddled topographies.

The experts and bureaucrats that appear in this article fall into three broad categories: mid-level officials of the Planning Department's legal division who are responsible for creating and updating building regulations; urban experts known as "urban curators" (curadores urbanos), who are selected by the city administration and are tasked with issuing building permits; and lawyers who advise developers, property owners, and the city administration on the legality and application of urban regulations. Within the city's administrative hierarchy, the Planning Department ranks as the highest authority, with powers to revoke building permits and plans. But the city's planning regime is a deeply contested domain, with intractable disputes falling increasingly under the jurisdiction of local and regional courts, the ultimate arbiters of urban laws. ${ }^{6}$ The practice of juridical archaeology lies at the core of these interpretative conflicts. 
In the remainder of this essay I trace the tactics that bureaucrats and experts employ to untangle Bogotá's convoluted legal regime. What bureaucrats describe as excavations to unearth legal facts in practice constitutes a means to lend authority to their navigations of an acutely indeterminate legal sphere. Experts working closely with developers in turn employ the notion of juridical archaeology to carry out real-estate ploys, while deflecting responsibility and concealing their interpretive labor. Ultimately, I argue that the practice of juridical archaeology calls attention to the symbolic force of bureaucratic infrastructures and their crucial role in conflicts over urban space. The fact that bureaucratic operators rely on a reified view of legal intricacies for their maneuvers is not simply a case of legal formalism. At stake are active practices of obscurantism and contestation that hinge on the thingified and performative power of legal excess and disorder. ${ }^{7}$

\section{THE PRODUCTION OF LEGAL TOPOGRAPHIES}

The 1970s complex that houses Bogotá's planning offices originally segregated the technocratic work carried out in a fifteen-story tower from the daily citizen traffic of a lower structure. But as one approaches the buildings today, it becomes clear that planning operations seep out of the institution and traverse it in myriad ways. Pasted on nearby walls are posters advertising brokering services, with signs that announce "building permits, plans, and procedures [trámites].”

Some of these brokers, or tramitadores, hover impatiently around the entrance of the building carrying forms and pens, offering to expedite procedures. Next to them are street accountants typing official documents on their aging typewriters. Inside the offices one encounters not a quiet space of enlightened governmental thinking, but corridors full of people milling about, making inquiries, and establishing connections with officials willing to listen to their bureaucratic plights.

Javier, an architect who had worked for years in the Planning Department, ${ }^{8}$ had a nuanced perspective on the ways in which Bogotá's legal regime had been shaped in daily practice. Like other city officials, during his career Javier had moved through circuits of legal expertise in and out of the Planning Department. He had previously worked in the office of an urban curator, a public-private agency close to real-estate developers, and had then returned to the Planning Department's legal division. More recently, he had been appointed to advise a high-level group of consultants working on the modification of the city's master plan. The team included former advisors to the national government, some with ties to the real-estate sector, as well as urban researchers working in academia 


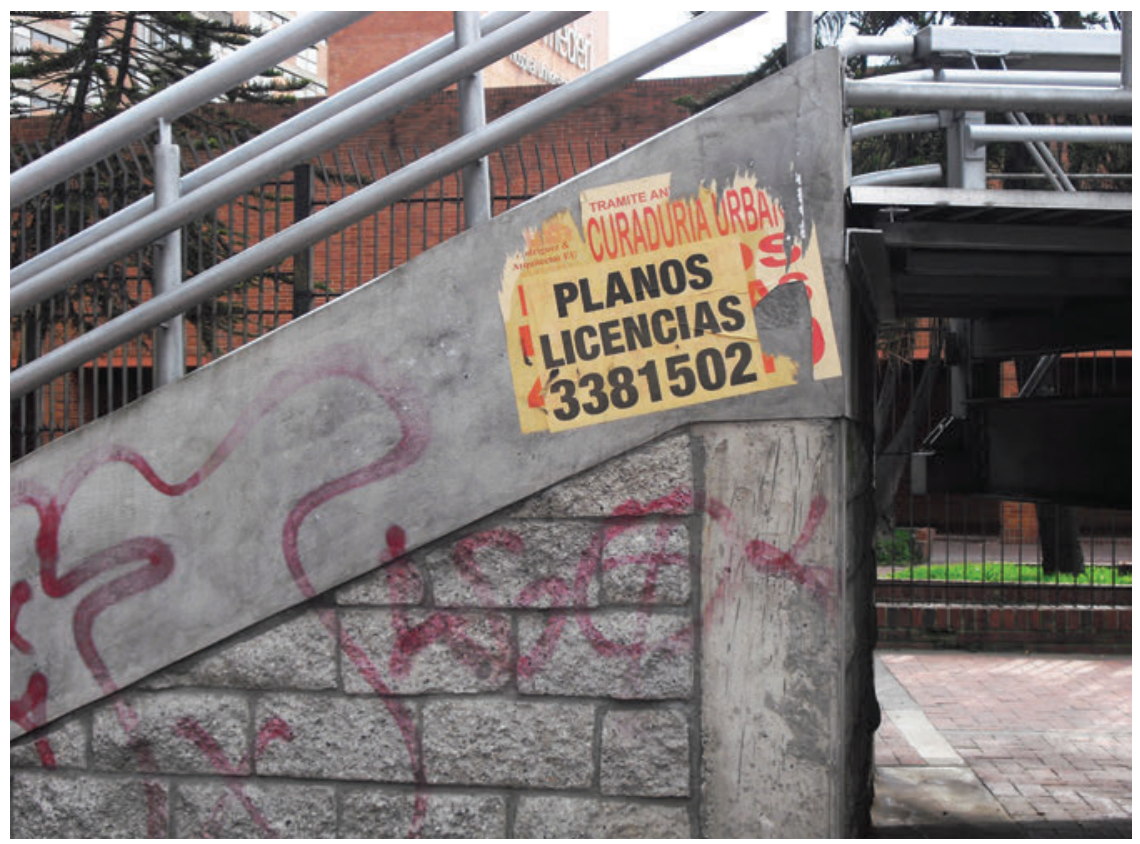

Figure 1. Brokering advertisements. Photo by Federico Pérez.

and consulting. Javier had become the de facto liaison between these planners and the bureaucrats charged with the department's everyday regulatory operations. As a result of his unique position, Javier had a detailed understanding of the city's various legal categories and how they were nested within each other and layered over time: from citywide master plans to regulatory decrees and building regulations for specific neighborhoods. He offered crucial insights into how the practice of juridical archaeology had been employed to carve out jurisdictions and establish legal force in the midst of the city's regulatory morass (cf. Richland 2013).

After months of informal conversations, Javier finally agreed to talk with me alone at the Planning Department, though removed from the official circuit of cubicles and boardrooms. We met in the building's lower level, next to the parking lot, in a small area that had become the designated hideaway for coffee breaks and gossiping. In the improvised common area, two unauthorized vendors sold snacks to the same authorities charged with regulating, among other activities, street vending. This space of professional intimacy (Herzfeld 2009) became the perfect setting for a conversation about planning contradictions. It also became a 


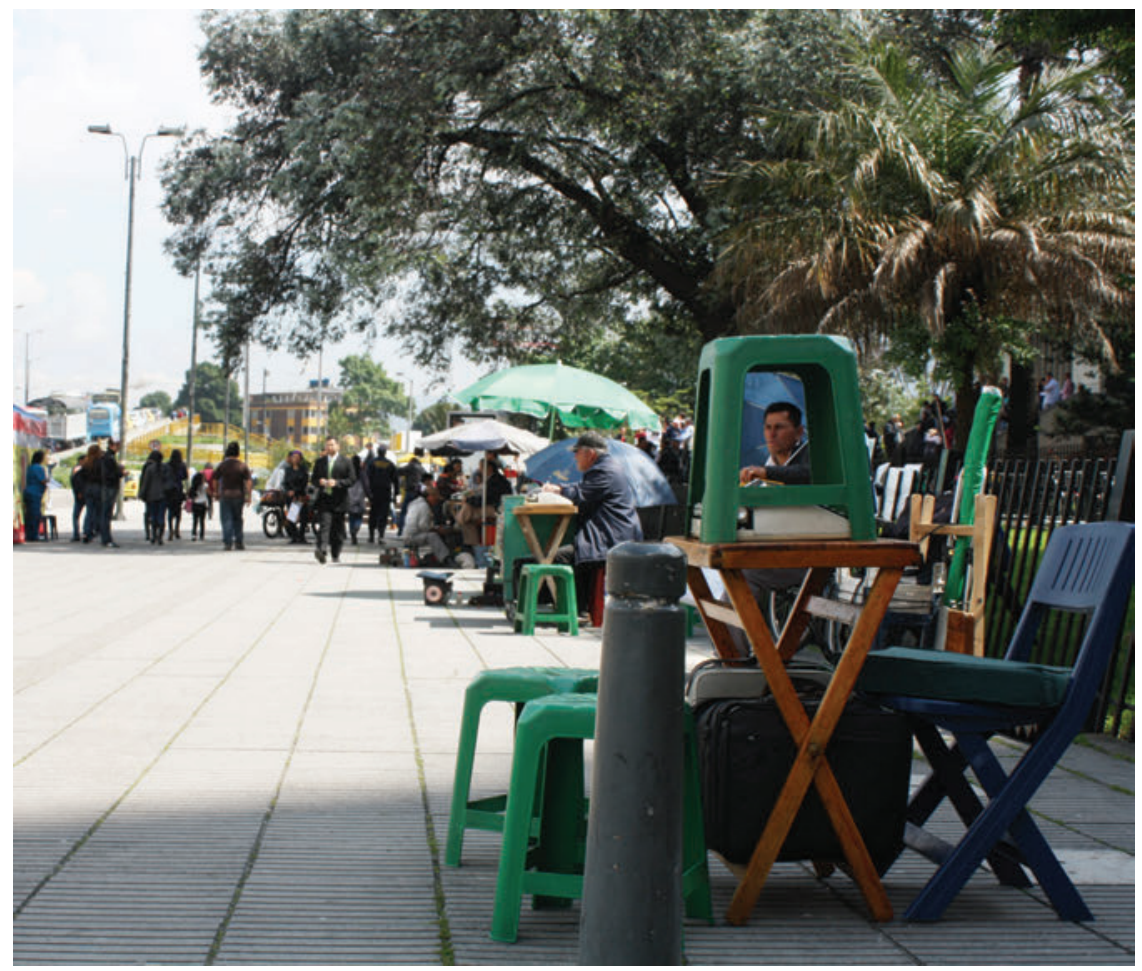

Figure 2. Street accountants. Photo by Federico Pérez.

forceful illustration of the extent to which anomalies are installed in the core of the state (Gandolfo 2013).

According to Javier, one of the main sources of Bogotá's legal profusion and confusion was the tendency to preserve certain zoning ordinances while simultaneously introducing new regulations. The logic of legal layering, Javier explained, started with the city's 1979 plan, Acuerdo 7 de 1979 (Agreement 7 of 1979). The plan's authors sought to preserve the regulations of neighborhoods they believed were "developing adequately." ${ }^{9}$ But planners went further, Javier noted, "and they started to make changes [to the original regulation] and introduce little things [such as new land uses]." In this manner, Javier continued, "[the Acuerdo 7] started to overlay little layers [capitas] on top [of the original regulation], so the original rule was no longer so original." What this meant, effectively, is that bureaucrats both maintained and modified urban regulations, exacerbating legal indeterminacy. 
In 1990 the administration created a new plan, the Acuerdo 6 de 1990 (Agreement 6 of 1990), which extended the logic of legal accretion. Here again, the criterion was to preserve the original regulation in neighborhoods that had had "good development." But the original regulation, Javier explained, had become exceedingly complex: "[The Acuerdo 6] preserves the neighborhood's original law, including the new layers of the Acuerdo 7, but now it also introduces new little layers [capitas]." The plan added more land uses, as well as specific modifications to building codes. Javier recalled, for example, how "people in the Planning Department came along and decided to create a thing they called 'roof utilization' [aprovechamiento de cubierta] stipulations: first it was the idea of the inclined roof, then an additional half story, and then a full additional floor." Once again, Javier insisted, they referred new building rules back to the "original regulation, but an original regulation that is always changing." In this manner, planners continued to insert legal fragments into a shifting regulatory field, while preserving the laws' ramifications into an uncertain legal past.

In 2000, the administration took the practice of overlaying regulations a step further. Following a national urban reform law (Law 388 of 1997) that gave greater planning powers to municipalities, Bogotá's city administration created its first comprehensive master plan, known as the Territorial Ordering Plan, or POT (Plan de Ordenamiento Territorial). The POT was intended as a paradigm shift away from the "legalistic planning" of the Acuerdo 7 and Acuerdo 6. It attempted to restore the management of urban space to the municipal government through a comprehensive "territorial strategy" and reduce the city's gray zones of legal interpretation. Specifically, the POT aimed to give greater control over planning regulations to the local state and eliminate an established practice in which public and private actors negotiated the details of development regulations (concertación de la norma).

Paradoxically, the plan's operationalization led to an even more indeterminate legal regime. According to Javier's para-ethnographic insights, ${ }^{10}$ some of the inconsistencies that emerged in this new wave of planning were directly linked to internal divisions in the city's planning bureaucracy. With the POT, planners sought again to preserve original regulations through an instrument that they now called "urban consolidation" (consolidación urbanística). The oxymoron of upholding an "original norm with all its modifications" was kept alive. This time, however, the plan introduced a crucial modification. While the layering of regulations in the Acuerdo 7 and Acuerdo 6 referred to all aspects of urban development, the 
POT separated the regulation of the physical aspects of construction from landuse stipulations. ${ }^{11}$

Javier explained this added layer of complication with an example. A middleclass neighborhood a few blocks from the Planning Department had been developed during the 1970s following a decree that allowed the construction of fivestory residential buildings and that made a provision for the preservation of an undeveloped lot on one side of the urbanization. "Then they modified the neighborhood's regulation," Javier recalled, "and they said: 'you can build ten-story office buildings on the undeveloped lot." At that point, "the decree was tied to land use, so residential buildings had to be five stories tall and offices ten stories." But then the POT was approved, and it differentiated building height from land use: "So I could now interpret this to mean that the ten-story buildings could be used both as offices and residential apartments." The alternative interpretation, Javier went on, was that the original decree should prevail - exactly the way it was applied in previous decades - and thus "I should assume that I can only have offices in ten-story buildings." Bureaucrats and experts became engaged in this way in an even more uncertain mode of legal reasoning. Urban regulation, Javier concluded, became "an issue of discretion."

What had originally been a project to strengthen authorities' control over land use and disentangle the city's regulatory regime, led to an even more intractable situation of legal indeterminacy. Crucially, Javier pointed out, this had happened as a result of the disconnection between high-level planners and lowlevel functionaries. While senior planners devised lofty design instruments in the upper floors of the Planning Department, lower-rank bureaucrats subverted these ideas when they translated them into everyday urban regulations. In the case above, for instance, bureaucrats created neighborhood-level regulations ignoring the POT's instruction to separate building stipulations from land-use rules. Javier claimed that "functionaries, the ones below, the ones that experience the daily [issues], did not acknowledge the changes made by the plan and continued to work under the logic of the Acuerdo 6 and Acuerdo 7." Out of habit or as a form of opposition, bureaucrats responded to the POT's call to preserve original building codes in certain areas with decrees that left intact zoning regulations from previous frameworks. In this way, they directly undermined experts' attempts to centralize the control over land use under the guidelines of the POT.

Bureaucrats reinscribed these older planning practices through an intermediate planning instrument known as Zonal Planning Units (Unidades de Planeamiento Zonal, or UPZs). By dividing the city into 117 UPZs, functionaries either main- 
tained the validity of older regulatory layers - particularly land-use regulationsor left gaps in the regulation. In Javier's words:

I'm not very clear if what is currently happening is that some UPZs are going beyond the framework provided by the Territorial Ordering Plan and the land uses it established. Or the other possibility is that by referring to the original decree - which under the plan's logic would only include building regulations-[and by not explicitly clarifying land uses], UPZs have opened a legal void (vacío normativo).

The production of Bogotás legal frameworks serves as a powerful reminder of the central place of human agency within the allegedly impersonal machinery of bureaucracy. Javier's insights countered ahistorical and disembodied portrayals of lawmaking and technocratic planning. His analysis debunked the myth of a timeless and universal law, and called attention instead to the contingent practices that constitute the law (Herzfeld 1992). At the same time, his narrative suggested that the accumulation of bureaucratic actions had produced a legal landscape surpassing bureaucrats' designs and expectations. He portrayed Bogotá's plans and decrees as an assemblage that took on a life of its own- "a legal Frankenstein,"12 as another bureaucrat once jokingly put it.

The talk of legal topographies and monstrosities resonates closely with scholarly calls to move beyond understandings of documents as representational devices and focus instead on their agentive qualities (Hetherington 2011; Hull 2012a, 2012b; Navaro-Yashin 2007; Riles 2006; Schwenkel 2015). Matthew Hull (2012b, 150), for instance, argues that the circulation of files produces forms of "collective agency" and "corporate authority" in Islamabad's planning bureaucracy. In a context closer to Colombia, Kregg Hetherington $(2011,132)$ looks at how a "network of documentary circulation" in Paraguay creates a "public sphere" that marginalizes rural landowners.

Although the accretion of urban regulations in Bogotá seems to follow a similar logic, the trajectories of legal complication sketched above suggest an incomplete and deeply contested bureaucratic formation. In Bogotá, as Javier suggested, the production of corporate authority is elusive, with institutional cleavages, policy shifts, and individual agendas continually resurfacing in the city's regulatory regime. The law's unstable temporality and materiality are recognized as the source of much confusion, and as a space for technical strategizing. Bureaucratic infrastructures prove contradictory and precarious, and their creative power lies in part in agents' ability to mobilize and naturalize them as obdurate 
material formations. It is here that bureaucrats and experts employ juridical archaeology as a means to harness the potentialities that lie dormant in the cracks and glitches of the city's legal system. To this end operators are constantly striving to reify the city's legal regime: they represent urban laws as part of an unruly apparatus or an opaque terrain that obscures individual agency and enables bureaucratic maneuvers.

\section{EXCAVATING AS LEGAL FORENSICS}

While conducting research in Bogotá's Planning Department I was struck by the many blueprints and old city plans hanging on racks in officials' cubicles. Worn out, creased maps from the 1970s were stacked on a large table in the building's public archive. Soon it became clear that these were not mere survivals from a remote planning era, but that they rather formed an integral part of Bogotá's everyday bureaucratic practices.

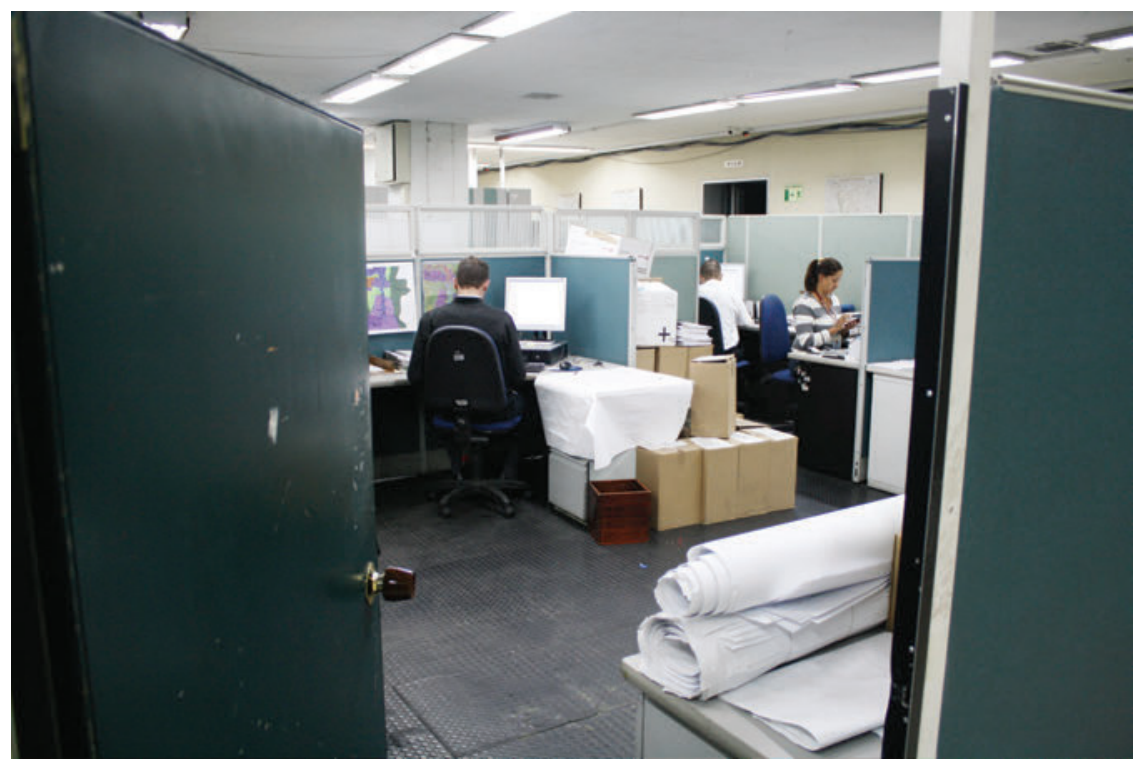

Figure 3. Planners at work. Photo by Federico Pérez.

For many officials, the progressive obfuscation of Bogotás legal regimes had been imprinted on the materiality of planning artifacts. The significance of the form and the technical aesthetics of plans was something that Rafael dwelled on as we talked in his office in the Planning Department. Rafael was a middle-aged architect and possibly the most experienced functionary in the department's legal 
division. Contrary to Javier, he had only worked in the Planning Department, for more than thirty years, epitomizing the bureaucratic habitus: a monotone voice that mechanically rehearsed a tired script of stipulations and rules.

At some point during our conversation, however, his performance was punctuated by a moment of intensity. He asked me if I had ever seen Bogotá's older master plans from the 1970s and 1990s, as he unfolded a yellowed sheet of paper on his desk. To an untrained eye, it appeared as a generic plan dotted with triangles, letters, and numbers. For him, the graphic representation was selfexplanatory: "You immediately knew what the specific regulation of a plot was only by glancing at the blueprint." The same was true, he continued, of the terminology planners employed at the time: "The plan had regulation polygons ${ }^{13}$ [polígonos de reglamentación], and naming only the polygon, you new what the lot's regulation was. For example, when they told you 'A-RG-02-3C,' you immediately knew 'A' was 'actualization,' 'RG' was 'general residential,' '02' was for land uses, and '3C' meant three floors with a continuous typology." "14

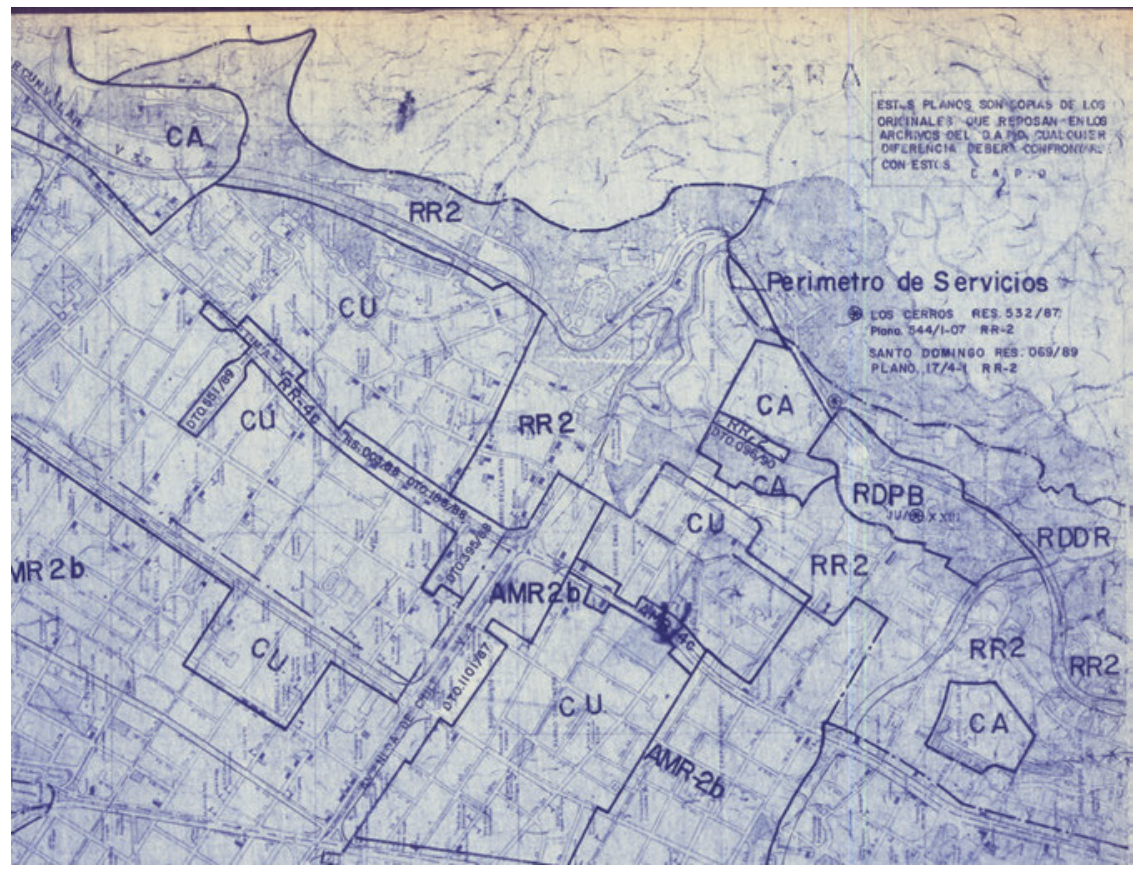

Figure 4. Section of a plan from 1979. Bureaucrats usually consider plans from this era more legible and transparent than later versions. Image courtesy of the Bogotá City Planning Department. 

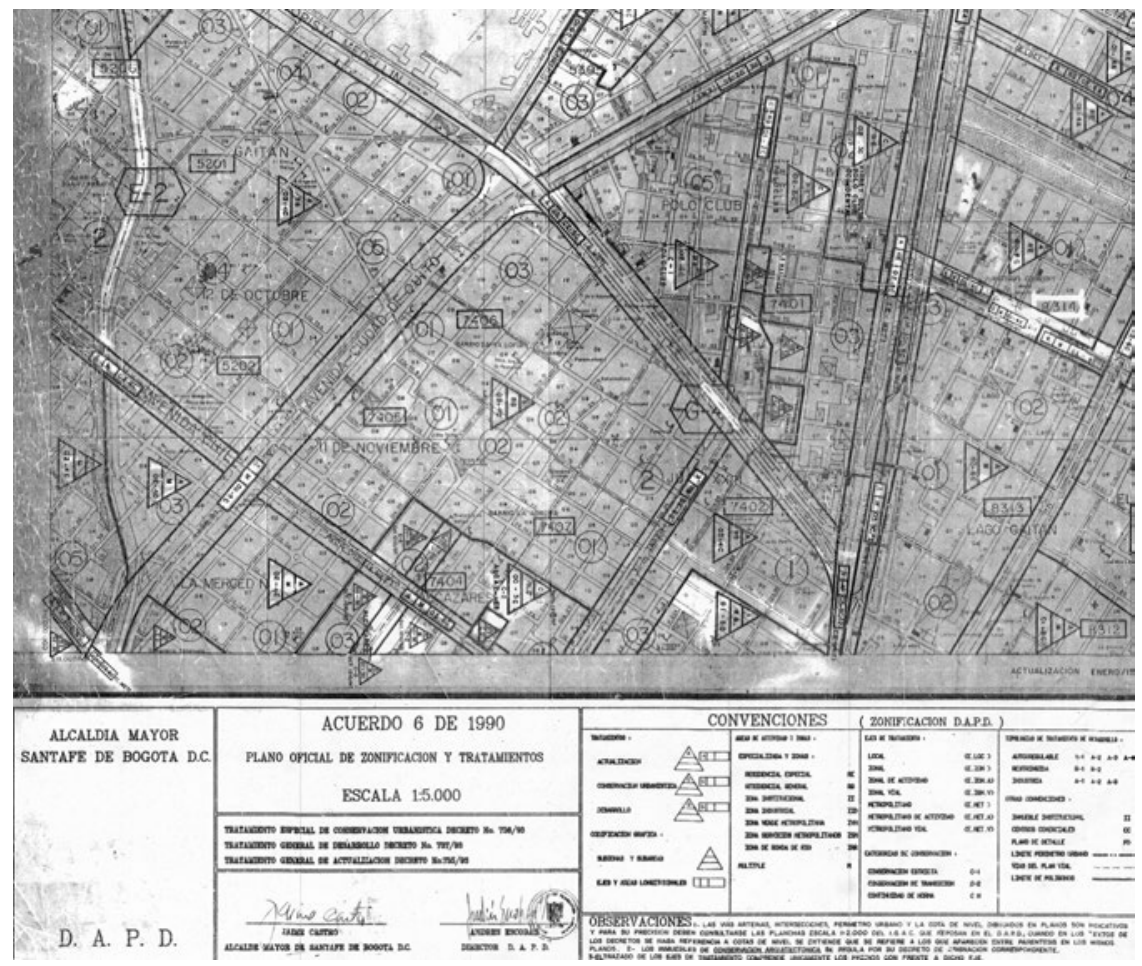

Figure 5. Section of a plan from 1990, whose conventions and graphic elements Rafael praised for their clarity. Image courtesy of the Bogotá City Planning Department.

Rafael's fetishization of old blueprints had intensified with the multiplication of the city's spatial and regulatory subdivisions, particularly with the creation of the POT and its hundred-plus UPZs. For him, this meant that rather than inspecting a single blueprint, he had to search through several plans to determine a specific regulation. "To find a plot's regulation," Rafael noted, "you now have to know in which UPZ it is located, and what regulatory sector, what subsector of uses, and what subsector of floor area ratios [apply]." He implied it was a question of successfully uncovering the precise regulation. Furthermore, he explained, this multilayered framework often included "footnotes" (notas) with additional specifications. "So it's very complex and it's easy to make mistakes."

According to Rafael, the POT's concept of "urban consolidation" exacerbated the city's already obscure processes of juridical amalgamation. When the UPZ classified an area as undergoing "urban consolidation," Rafael pointed out, "you have to carry out a regulatory archaeology [arqueología normativa] to try to determine how [the original regulation] has changed through time." Some pro- 
cesses were easy to trace, so that reconstructing the original decree was not a particularly contested affair. In other situations, overlapping regulatory logics created great uncertainty among bureaucrats. Here again Rafael talked about archaeology as an exact science that could uncover correct juridical meanings. In actuality, and as other experts admitted, far from an exercise in fact finding, the practice of juridical archaeology was essentially about manufacturing plausible legal truths among the assortment of regulations suitable to particular development projects.

"When you study a property or a plot under urban consolidation," Rafael explained, "you have to find out when and through what resolution or decree it was approved and what kind of zoning it had forty years ago." If the plot appeared under environmental conservation (conservación ambiental) in the blueprints of the Acuerdo 7 in 1979, then the original decree would continue to be valid. The legal archaeologist would have to study if the Acuerdo 7 had introduced any additional changes or new layers. Finally, "if the plot appeared under 'regulatory continuity' [continuidad de norma] in the Acuerdo 6 [of 1990] and under 'urban consolidation' in the POT [of 2000]," Rafael continued, "then the original decree continued to apply." But here again, this meant the "original decree with all its modifications."

This was the easy scenario. "The complicated one," Rafael explained in fluent bureaucratic parlance, "is when you have urban consolidation and you start to go back and it turns out that the plot was not under ' $\mathrm{CN}$ ' [regulatory continuity] in the Acuerdo 6 but for example 'A RE 01 4C' [actualization, special residential, 01-land uses, 4C-four floors continuous typology].” Beyond the technical specificities of these categories, Rafael was pointing out that original decrees could be simultaneously preserved and fundamentally modified through time as a result of contradictory legal concepts issued at different points in an area's regulatory history. In Rafael's example, even though the law required him to trace a plot's original regulation, other laws and decrees could at the same time substantially transform regulations at different points in their trajectory.

Interpreting urban laws entailed a meticulous process of excavation, Rafael explained: a process of sifting through plans and regulations to ascertain where the legal bedrock lay. "So when you deal with urban consolidation," Rafael outlined, “you can't really go to the original decree because an older master plan already blocked it. In other words, you descend until the regulation starts to change." How deep one should “descend” in the city's legal topography was not 
a self-evident matter. It was an issue of tracing the moments at which experts had attempted to legally freeze a particular spatio-juridical configuration.

Bureaucrats faced other ambiguities. The POT added supplementary regulations known as fichas (guidance documents), which in many cases remained incomplete. So, for example, Rafael explained, of the ten construction items that a decree regulated in a plot — setbacks, height, front-yard requirements, etc.in certain UPZs a ficha would include only six, and "for the remaining items you had to keep going down." In this scenario, a ficha might establish new conditions for the height of a building, but say nothing about setbacks from the street. "So you don't know what to do," Rafael observed, "and you have to continue descending and if the Acuerdo 6 [of 1990] tells you it's regulatory continuity, then you have to continue descending, and in the end you get a decree with a lot of rules.”
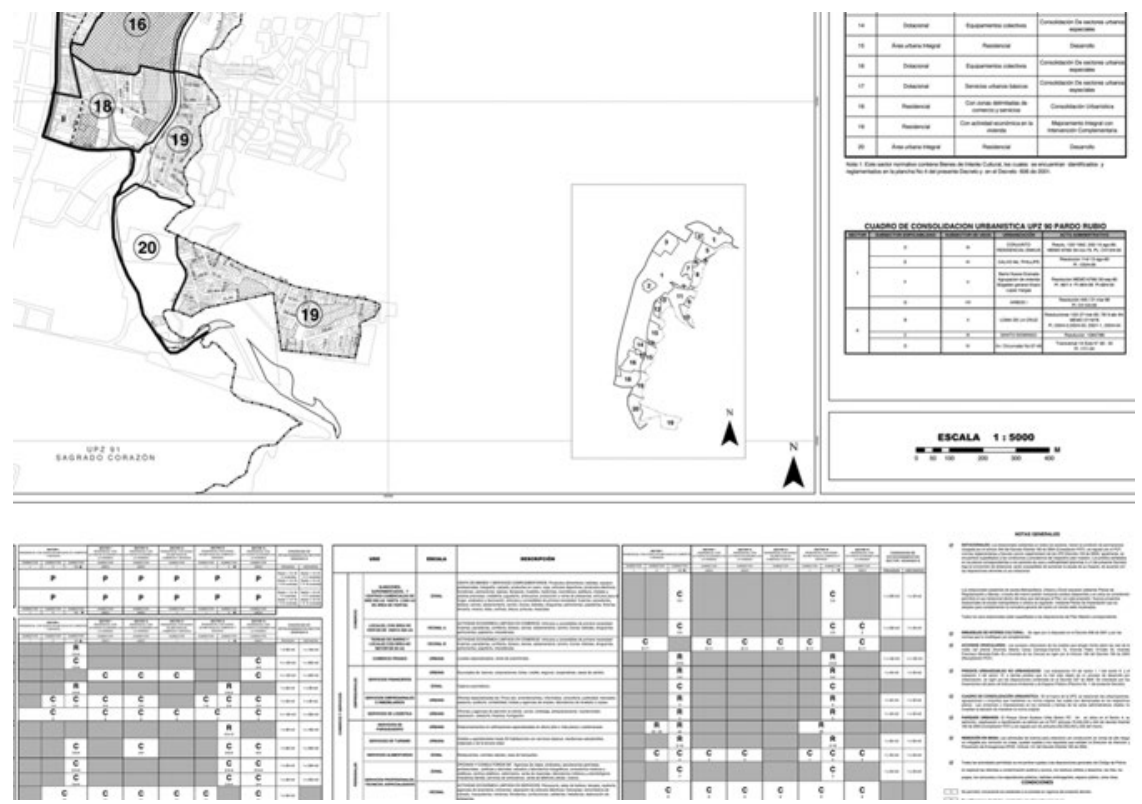

Figure 6. Section of a Zoning Planning Unit from the 2000 Territorial Ordering Plan. This is an example of the increasing complexity of plans, particularly with the addition of notes and categories. Image courtesy of the Bogotá City Planning Department.

Juridical archaeology is not the search for hidden juridical meanings. Its main objective is not to uncover preexisting regulations in the city's legal substrata, but rather to strategically configure legal frameworks in a field of bureaucratic contingency. In practice, it consists in stitching together regulations and 
decrees from the city's shifting and contradictory legal regimes. From this perspective, juridical excavations would be best described as forms of bureaucratic bricolage in which experts assemble urban regulations drawing on disparate frameworks. Such practices produce amalgamations made up of incongruous elements. This uncertain juridical system — with the multiple resources it makes available to legal strategists and the aura of authority it projects - ultimately emerges as a crucial stage for interpretative battles about how urban space should be produced and regulated.

Bureaucrats like Rafael employed the idiom of juridical archaeology to give their legal performances a semblance of objectivity and authority. In his words, "we carry out a rigorous study of the law, we issue a technical concept about specific regulations, and we determine if a project is correct architecturally and urbanisticamente." 15 It is precisely by reifying the city's legal regime and representing it as a stratified and opaque legal terrain that juridical archaeologists can either deflect accountability — arguing that legal imperfection is to blame - or occlude their interpretative agency, claiming that they do not shape the meaning of the law but only unearth it from the city's legal depths.

Bureaucratic disorder can be both a resource and a hindrance for different actors in different circumstances. Legal ambiguities emerge as fields in which multiple stakeholders struggle over authority and expertise. Divergent projectsfrom unbridled real-estate speculation to the regulation of land markets - are enabled, distorted, and potentially subverted by the technicalities of the law (Riles 2005). But technicalities in themselves do not explain such trajectories. Instead, it is necessary to consider the ways in which agents shape and mobilize technical resources. In Bogotá, experts and bureaucrats obscure their interpretative agency by fetishizing legal technicalities as strata in a convoluted legal topography. ${ }^{16}$ In this sense, different actors enact juridical archaeology for a variety of purposes. For bureaucrats such as Rafael, the archaeological trope is integral to the performance of bureaucratic authority. Representing the city's legal regime as a tangible and intricate formation reinforces the idea of bureaucratic work as a form of legal forensics. This is crucial for functionaries who must reassert their official status in the city's juridical field, and particularly within the volatile environment generated by a tradition of legalism and bureaucratic excess. Meanwhile, for other agents such as private lawyers and bureaucratic brokers, juridical archaeology constitutes a means to contest authoritative knowledge, undercut planners' designs, and advance particular agendas. It is to these actors that I now turn. 


\section{THE DEVIL IS IN THE DETAILS}

"The devil is in the details." This is how a lawyer named Camilo described the power struggles associated with the city's planning code during a conversation we had in a busy café in 2010. We were discussing a conflict that involved the development of a twenty-five-story office building in the parking lot of Unicentro, a shopping mall built in 1976 . The developer had recently obtained the building permit based on regulations from the 1970s that conflicted with current decrees. The case was exemplary of the tensions created by the official preservation of older regulations in the midst of urban change. Residents from the surrounding area had mobilized to oppose the expansion project, outraged by the prospect of a large tower in the already congested low-rise neighborhood. Planners were frustrated by yet another situation in which their authority had been undermined, as they attempted to prevent the construction.

The building permit for the Unicentro office tower had been devised from one of the many excavations performed in the city's legal topography. According to Javier, the architect from the Planning Department who had explained to me the intricacies of Bogotá's legal landscapes, these were practices that emerged from the "breeding ground" (caldo de cultivo) of the city's convoluted legal regime: “There's typically a case and you have all those regulatory conflicts and then someone proposes an interpretation and resolves the situation. The solution does well because nothing happens, [no one contests it], and then everyone assumes it's the right way to do it. It sets a precedent [hace escuela] and everyone starts using the same approach." This is how lawyers and brokers who "carry out the archaeological work," Jairo concluded, "[become] experts.” Typically, other legal experts and officials eventually come along and dispute a specific "reading of the law." In his words: "[New experts] expand the archaeological work, and that is when conflicts start to occur - all those problems and consultations in the Planning Department - until the accepted interpretation changes." According to him, this is how the city's legal complications created the need for people who knew "all that archaeology": "That's where the city's great experts come into the scene, those people who everyone consults."

One of these "great experts" was Emilio, an attorney who advised the country's largest developers. Despite deriving his authority and considerable earnings from the city's legal confusions, Emilio was known for his criticisms of Bogotá's cacophonous legal system. In academic and policy conferences he typically started his interventions by unrolling several yards of paper with a list of the city's development regulations. We met in his office in Bogotá's financial district, which 
occupied an entire floor in the headquarters of one of Colombia's main construction companies. Emilio spoke quickly and paced energetically around the luxurious boardroom as he explained his annoyance at the city's bureaucratic disarray: “There isn't a greater seed for corruption than regulatory voids or legal exaggerations. Behind these things there's always the idea that we have to go to the Planning Department to negotiate and that's terrible." For him, Bogotá suffered from a "drama of [multiple regulatory] languages." According to Mónica, an associate lawyer in the firm, Bogotá had at least "four different legal regimes operating at the same time," and "in order to obtain a building permit, you have to examine fifteen, twenty, or more decrees and regulations." In their view, it was primarily "the law's poor quality" that made legal interpretation an "extremely complex operation.”

Leonor, an experienced architect who had worked in the public and private sectors, had a similar perspective on the city's planning regulations. As one of the city's five designated urban curators, Leonor was in charge of issuing building permits. The figure of the urban curator was created by national decree in 1995 to decongest planning offices throughout the country. But as Leonor admitted, "no one really knows if we are public sector or not." She described the high costs of office operations and emphasized how the supposedly public service she offered was ruled by market efficiency and competitiveness. By outsourcing the interpretation of urban laws to experts such as Leonor, the government sought to streamline municipal bureaucracies and reduce bribes between developers and city officials.

In reality, however, rather than eliminating corruption, urban curators often removed such practices from the Planning Department and institutionalized them in their new semipublic offices. Instead of allowing low-paid bureaucrats looking to strike deals in exchange for "generous" interpretations or for "giving away the law" (regalar la norma), ${ }^{17}$ the decree established a system of compensations for curators based on the number of square meters of new construction they licensed each year. This created a strong incentive to favor developers' interests, while remaining liable for any irregularity in their interpretation of urban regulations. In this regard, the curator who had issued the controversial Unicentro mall license had candidly acknowledged the extent to which construction licensing had become monetized in an article published in 2007 in the country's main newspaper, El Tiempo. "And what's wrong with a curator making 80 million [a month] [approximately $\$ 40,000]$, when he or she will later have to pay for attorneys to deal with 
lawsuits against him or her?" she had asked a journalist who was suggesting that the government had "handed over a good business" (Angarita Meneses 2007).

Back in her office, Leonor criticized the indeterminacy of the city's legal administration. Like the real-estate lawyers, she complained about urban laws' "terrible flaws," although such legal confusions were precisely what gave experts like her some wiggle room in their job. For her, the city's development conflicts were associated with the Planning Department's technical incompetence and the lack of knowledge about on-the-ground dynamics. "It's one thing to be an advisor over there [in the Planning Department], looking toward the city [from above]," she explained, "but when you actually implement the law [aterriza la norma], eighty mistakes suddenly arise." Instead of talking about the political nature of the city's planning conflicts, Leonor highlighted their technicalities, envisioning an eminently technical solution. In her estimation, "the city should have something like a council of elders to resolve those issues, but from a strictly legal and technical perspective." She stressed the technical acumen of these hypothetical elders, implying that they would resolve all confusion and vagaries of legal practice by establishing the city's definitive legal truths. Like many experts, Leonor minimized the role of interpretation in her job; in fact, at times she denied it altogether. "Curators, us, we can't interpret, let's start from there." She reaffirmed the supposedly neutral, technocratic nature of her profession. This deflected any potential liability toward the Planning Department and concealed curators' own interpretive maneuvers.

Hinting at the controversial Unicentro case, which had received wide coverage in the news at the time, Leonor commented on how the Planning Department created new requirements or reversed previous edicts always appealing to the idea that "the city had changed." In the case of Unicentro's twenty-five-story building, authorities had argued that the regulations allegedly allowing the construction had been issued decades earlier, when urban densities and traffic in the area were much lower. For Leonor, however, such rules continued to form part of the city's legal framework and had only been partially reformed in recent decrees. "[Planners] say: 'In the 1970s the city had 2 million people, now it has 9 million.' [But my question is,] why didn't they say that in the Territorial Ordering Plan, in the law." In her view, if planners had a clear vision of how urban development should proceed, they ought to translate it effectively into legal language; otherwise, they did not have grounds on which to controvert technically feasible readings of the law. 
Interpretations such as those surrounding the Unicentro case were valid, in her view, because they were plausible under the city's legal disorder. Leonor appealed to a version of legal technicality that was neutral and noninterpretative; hers was a quasi-mechanical operation that legitimated specific outcomes, even if these were anachronistic, inconsistent with existing urban policies, or opposed by considerable numbers of citizens. Technical rigor became the preferred alibi for controversial rulings. Here she, too, appealed to the archaeological trope. In her words: "I always say that we [urban curators and experts] perform a kind of urban archaeology. So it's like we search, search, and search, and I don't know where we're going to arrive and what we're going to find. All of this is really absurd." With the discourse of juridical archaeology Leonor reified a chaotic legal space where experts like her only searched for legal precedents, instead of actively interpreting or shaping them.

Leonor, Emilio, and Mónica bemoaned the city's unruly legal landscapes despite exploiting legal disorder and excess as brokers for the real-estate industry. Their misgivings put the burden of planning conflicts on legal technicalities, obscuring their role as administrative operators. In this sense, fetishizing the lawas an intricate and contradictory legal topography-emerged as a key tactic in their struggles over authority and legitimacy. At the same time, their complaints were a symptom of their loosening grasp on the city's legal instruments. The city's palimpsest of laws had become increasingly difficult to mobilize, ultimately limiting, delaying, and blocking many development projects. Legal brokers walked a fine line between successfully maneuvering in a reified space of juridical complexity and being bogged down by the city's increasingly indeterminate legal system. The Unicentro case was emblematic of this legal unpredictability.

The building permit for the mall's twenty-five-story annex was issued by a curator's office in 2009. Although the Planning Department did not have the competency to block the license for procedural reasons, it called for the action of the tribunals and publicly denounced the project through an official resolution, stating that the developers had "transgressed the city's juridical order and had interpreted urban regulations going against the Constitution." The mall's administration defended the legitimacy of the construction by calling it a "remodeling project" permissible under the original regulations of the plot. In an article published by the news website La Silla Vacía in 2010, the mall's lawyer commented, “Unicentro's original license is from 1974, and according to the procedure of urban consolidation, it must be developed following the original regulations that authorized [the development of the area]" (Rico 2010). Leonor, the curator, had 
a similar opinion. As she put it: "It's absurd that the Planning Department says that it wants to consolidate regulations, and at the same time it issues guidance documents changing the floor-area ratios and the construction allowances; that's when people start making strange hybrids [injertos]." Planners, in turn, attempted to assert the preeminence of more recent regulations, such as the 2000 Territorial Ordering Plan. According to a planner who was also interviewed by La Silla Vacía, "if a building is being developed in the future, then it must be ruled by the regulations of the future" (Rico 2010).

In 2011, an administrative court revoked the building permit and suspended the curator who had issued the license. In the following years, the Planning Department and the mall's administration negotiated the conditions under which a new license would be eventually issued. By the end of 2013 the mall had requested a new building permit in another curator's office and neighbors were again rallying to oppose the project.

At stake in these conflicts was control over a hermeneutic field. Fetishizing the law under the guise of juridical archaeology became a fundamental yet unstable tactic for legal manipulation. In some cases a rich trove of legal resources was plumbed, with experts assembling and deploying certain codes depending on their development agendas; in others, they encountered a more intransigent field controlled by bureaucrats at the Planning Department. This tension explained the ambivalence with which lawyers and curators talked about and engaged the city's legal regime: it surfaced as a convoluted terrain that both enabled and imperiled their expert practices.

The idiom of juridical archaeology reveals different locations and capacities within a variegated ecology of legal expertise. "Constructions of the state," Akhil Gupta (2012, 104) notes, "vary according to the manner in which actors are situated." Among civil servants such as Rafael, the practice of juridical archaeology forms part of an attempt to assert their position within the city's planning apparatus. The high stakes of development agendas, along with a tradition of bureaucratic disrepute, make the city's planning bureaucracy a particularly contentious and perilous place. Mid- and high-level officials are the frequent targets of investigations conducted by Bogotá's Comptroller's Office (Contraloría de Bogotá), many of which are politically motivated and can lead to dismissals and prolonged lawsuits. Fetishizing legal topographies becomes a way of coping with heightened uncertainty, professional vulnerabilities, and a widespread sense of bureaucratic failure - what Andrew Mathews $(2011,160)$ calls the "structural paranoia" of bureaucracy. Meanwhile, private actors who gravitate around the city's planning 
bureaucracy - lawyers, urban curators, and experts - redeploy juridical archaeology with more flexibility and in an almost entrepreneurial fashion. They destabilize bureaucratic authority and wrest control of legal instruments, drawing on what are often far superior technical and financial resources.

This politics of juridical archaeology was brought home to me during a conversation with José, a retired urban curator. According to him, the idea that urban laws had formed overly complex legal topographies was a fabrication. "No, no, no, chief," he told me impatiently in his downtown office, "that's what developers and their advisors [técnicos] want us to believe." A complex city such as Bogotá, he continued, required a complex regulatory system. "I was an urban curator for ten years, so I know the law's complexity, the numerous regulations that exist, and I never had trouble applying regulations. I'm a legal expert [experto en normas] and that's what I do." Unlike other urban curators, José was decidedly against market-driven development. "What is very complicated," he explained derisively, "is applying regulations at the whim of developers. So that's precisely why developers say it's too complicated, because they encounter barriers, laws, that don't let them do what they want!"

\section{CONCLUSION: Performing Bureaucratic Infrastructures}

The complexity of urban laws is in part derived from the heterogeneity and ever-changing character of urban space. Planning law, according to Mariana Valverde $(2012$, 203), is a "regulatory maze" to which new rules and concepts are continually added. The site-specific and historically cumulative nature of municipal regulations produces legal instruments ruled by contingency. The practice of juridical archaeology, however, calls attention to the ways in which urban actors themselves rely on ideas of legal complexity in everyday practice. Legal operators - from city officials to bureaucratic brokers and urban lawyers - work the system by maintaining the image of a stubbornly ambiguous and unstable landscape. They mobilize the notion of juridical archaeology and objectify spaces of techno-legal improvisation to claim authority, deflect responsibility, and contest the expertise of others.

In the words of Camilo, the lawyer whose words opened the previous section, "the law is a battlefield, and the more laws and juridical rulings you dig up for your trench, the more effectively you can win positions and do better in legal disputes." For him, the practice of juridical archaeology was irrevocably political, a war of position in which legal weapons acquired their efficacy through the archaeological excavation of a sedimented topography. Just as spatial meta- 
phors naturalize images of a unified and transcendent state (Blomley 2013; Ferguson and Gupta 2002), juridical archaeology evokes subterranean legal substrata with allegedly foundational powers. From this perspective, legal strategizing is not primarily about creating zones of exception (Ong 2004; Roy 2009). Rather, it is dedicated to multiplying excess and complexity, and to evading scrutiny in what appears as a murky legal topography.

The apparent depth and solidity of the city's legal terrain is crucial in this regard. But as I have shown, this should not lead us to displace political agency onto bureaucratic artifacts. In fact, privileging material agency in the analysis of Bogotá's planning regime would amount to reproducing operators' strategic attempts at legal reification. Equally at stake are agents' representations and uses of bureaucratic forms in distinct contexts. In this sense, my discussion points to the performances and interactions through which bureaucracy is materialized: the pragmatic and ideological processes through which particular material properties are enacted and rendered consequential. While critiques of the dominance of representation and subjectivity in the social sciences may have swung "the pendulum too far toward materiality," my approach here follows the call to "promote equality, a dialectical republic in which persons and things exist in mutual selfconstruction” (Miller 2005, 38).

In Bogotá, the putative materiality of the legal topography - its sedimented quality as a corpus that must be excavated - emerges as a strategic idiom that allows experts to obscure and contest legal practice. Bureaucratic infrastructures are not merely material networks that enable techno-political action, and legal complexities are not simply a function of excessive formalisms and technicalities. In their reification of legal process, juridical archaeologists appeal to the symbolic power of bureaucratic assemblages. They actively produce and deploy images of obduracy and material complexity - they perform bureaucratic infrastructure - as a means of manipulating the law.

\begin{abstract}
In Bogotá, urban planners employ the notion of juridical archaeology to describe the difficulties associated with the implementation of the city's profuse and contradictory building regulations. They evoke a stratified and recalcitrant topography of decrees whose unpredictable effects are tied to the juxtapositions and gaps between sedimented legal artifacts. In practice, however, juridical archaeology holds great strategic value to bureaucratic operators, as it enables them to configure frameworks for urban development in a field of regulatory contingency. By representing the city's legal system as an opaque and intricately layered terrain, bureaucrats and lawyers deflect
\end{abstract}


accountability, arguing that incoherence is to blame. Furthermore, they occlude their interpretative agency by claiming that they do not shape the meaning of the law, but merely excavate it from the city's legal depths. I argue that juridical archaeology expands understandings of state reification, showing that bureaucratic disorder itself can be reified as a concrete amalgamation of incompatible parts and pieces. Furthermore, I qualify scholarly claims about the agency of bureaucratic artifacts through a more interactive approach to materiality that highlights the crucial roles of social meaning and practice. From this perspective, I focus on the ways in which actors materialize legal infrastructures in their everyday performances of bureaucratic expertise and authority. [city planning; law; bureaucracy; materiality; expertise]

\section{NOTES}

Acknowledgments I am grateful to my interlocutors in Bogotá and, in particular, to Juan Felipe Pinilla and Armando Lozano for sharing with me their critical insights into and deep understanding of the city's planning laws. I thank Steven Caton, John Comaroff, Namita Dharia, Susan Fainstein, Alex Fattal, Michael Herzfeld, Matthew Hull, Jeffrey Kahn, Nick Smith, Ajantha Subramanian, Kimberly Theidon, Anand Vaidya, and the participants in the Harvard Political Anthropology Working Group and the "Paper Life of Politics" panel at the 2015 annual meeting of the American Anthropological Association for their valuable suggestions and inspiring conversations. Finally, my sincere gratitude to Cultural Anthropology's anonymous reviewers, the editorial collective, and especially Cymene Howe for her generous and perceptive editorial guidance. The research on which this article is based was supported by the Wenner-Gren Foundation, the Inter-American Foundation, and the Social Science Research Council.

1. Much like Michel Foucault's (1972) archaeological analysis, the practice of juridical archaeology is oriented toward the present. But far from identifying a matrix of intelligibility (an episteme), juridical archaeologists combine and juxtapose fragments of the city's juridico-spatial trajectories strategically. In so doing, they reify legal process as static assemblages of historical traces. A parallel problem in Foucault's archaeology is the emphasis on ruptures and the lack of attention to processual temporalities.

2. I am referring, here, to Latourian understandings of assemblage that emphasize an expansive and symmetrical distribution of agency among humans and nonhumans, which typically remains invisible to social actors. In contrast, the practice of juridical archaeology calls attention to the intentional and conscious ways in which people interact with things and, most important, the mutual and constitutive relationship between humans and nonhumans, sociality and materiality (see Miller 2005).

3. While anthropological work has rarely focused directly on urban laws, a growing literature in legal geography has emphasized the distinctive complexities of the city as a legal space (Blomley 2013; see also Valverde 2012). My analysis parallels these critiques' emphasis on the politics of legal spatializations through concepts such as jurisdiction and scale.

4. I view fetishism as a form of reification. In contrast to negative understandings of reification that conceive it as the passive objectification of social reality, I suggest here that it produces socially and political active things or fetishes. See Silva 2013 for a recent discussion of the analytical relationship between reification and fetishism.

5. In a critical review of Matthew Hull's Government of Paper, Constantine Nakassis (2013, 403) defines materialization as the performative actualization of material qualities in social life and argues that "materiality is not 'in' anything at all, even if we often experience it as such; rather, it is a relationship across events of semiosis." 
6. Other institutional actors actively engaged in these disputes are oversight organizations such as the Bogotá Comptroller's Office (Contraloría de Bogotá D.C.) and the local ombudsperson (Personería de Bogotá D.C.).

7. The "thinging of the thing," in Martin Heidegger's $(1971,178)$ suggestive words, sets things apart from objects and calls for an understanding of their eventful and transformative nature. Tim Ingold (2012) elaborates on this distinction, arguing that objects are distant and readymade, while things are proximate and in an ongoing process of formation. I use thingified here in a similar vein to underline the interactive and mutually constitutive relationship between people and things.

8. Local governance in Bogotá has changed significantly since the 1980s with the introduction of the popular election of mayors (1986), the creation of a special statute to strengthen the city's administrative apparatus (1993), and a national urban reform law (1998) giving cities greater planning powers. The Planning Department has gained prominence with these transformations. Although it is only one of the twelve administrative sectors that make up the city administration, it is responsible for the production of urban regulations and the creation of the administration's government program (plan de desarrollo) and master plan (plan de ordenamiento).

9. In Bogotá, planning would be best described as a hybrid system (Salazar Ferro 2007) in which legalistic planning (planeamiento normativo) coexists with social-spatial approaches. Bureaucrats produce plans that are sanctioned as laws in the form of decrees (decretos), resolutions (resoluciones), or agreements (acuerdos). In this sense, planners work as lawmakers, continually codifying their expert assessments of urban transformation into legal instruments. The fact that most city-planning officials are architects by training is not irrelevant. It shapes their representations of the law, leading them to insist on an almost geometric legal logic in which urban laws and built forms are isomorphic. In this regard, a lawyer once mocked architects' inflexibility by saying: "Architects are more Catholic than the pope!"

10. Douglas Holmes and George Marcus (2005, 237) define the para-ethnographic as "the de facto and self-conscious critical faculty that operates in any expert domain as a way of dealing with contradiction, exception, [and] facts that are fugitive." Javier had a keen ethnographic sensibility that allowed him (and me) to reflect on the sociocultural and political dimensions of planning technicalities.

11. Zoning laws now separated floor-area ratios (edificabilidad) from land uses (usos).

12. This trope represented a more direct acknowledgment of the agency of planners as the makers of legal monstrosities in their bureaucratic laboratories. I thank an anonymous reviewer for this point.

13. In the local planning jargon, polygons referred to areas of varying size and shape (from individual plots to entire blocks or neighborhoods) that were marked out on city plans.

14. These categories were called treatments (tratamientos), and they established the basic conditions for the management of urban space: conservation referred to historic and architectural preservation laws, actualization established regulations for the redevelopment of constructed parcels, and development included guidelines for the development of empty lots.

15. In Spanish, urbanístico refers specifically to the expert and regulatory practices associated with urban planning.

16. Here, again, it is crucial to reconceptualize fetishism as a social practice. In contrast to understandings based on the Marxist commodity or on Freudian psychological displacements, my usage recovers the performative and ritualistic dimensions of the fetish found in classical anthropological theorizations. The key point here is that fetishism is not primarily an ideological category, in the sense of an unaware and mystified individual who is rendered passive by her or his misrecognition of an objectified reality. Rather, it is a transformative activity in which individuals are self-consciously engaged, albeit also entranced: in materializing certain social realities, individuals also become beholden to their power. 
17. "Giving away the law" is a pervasive idiom among planners and perhaps the clearest example of the reification of the law: in this case, literally as a commodity that can be bargained with and exchanged.

\section{REFERENCES}

Abrams, Philip

1988 "Notes on the Difficulty of Studying the State." Journal of Historical Sociology 1, Anand, Nikhil no. 1: 58-89. http://dx.doi.org/10.1111/j.1467-6443.1988.tb00004.x.

2011 "Pressure: The PoliTechnics of Water Supply in Mumbai." Cultural Anthropology 26, no. 4: 542-64. http://dx.doi.org/10.1111/j.1548-1360.2011.01111.x.

Angarita Meneses, Patricia

2007 "Salarios de 80 y 100 millones de pesos reciben mensualmente los curadores urbanos." El Tiempo, March 1. http://www.eltiempo.com/archivo/

Appel, Hannah documento/CMS-3457688.

2012 "Offshore Work: Oil, Modularity, and the How of Capitalism in Equatorial Guinea.” American Ethnologist 39, no. 4: 692-709. http://dx.doi.org/10.1111/ j.1548-1425.2012.01389.x.

Appelbaum, Nancy P.

2013 "Reading the Past on the Mountainsides of Colombia: Mid-Nineteenth-Century Patriotic Geology, Archaeology, and Historiography.” Hispanic American Historical Review 93, no. 3: 347-76. http://dx.doi.org/10.1215/00182168-2210768.

Blomley, Nicholas

2013 "What Kind of Legal Space is a City?" In Urban Interstices: The Aesthetics and the Politics of the In-Between, edited by Andrea Mubi Brighenti, 1-20. Surrey, U.K.: Ashgate.

Coronil, Fernando

1997 The Magical State: Nature, Money, and Modernity in Venezuela. Chicago: University Feldman, Ilana of Chicago Press.

2008 Governing Gaza: Bureaucracy, Authority, and the Work of Rule, 1917-1967. Durham, N.C.: Duke University Press.

Ferguson, James, and Akhil Gupta

2002 "Spatializing States: Toward an Ethnography of Neoliberal Governmentality." American Ethnologist 29, no. 4: 981-1002. http://dx.doi.org/10.1525/ae. 2002.29.4.981.

Foucault, Michel

1972 The Archaeology of Knowledge, and the Discourse of Language. Translated by A. M. Sheridan Smith. New York: Pantheon.

Gandolfo, Daniella

2013 "Formless: A Day at Lima's Office of Formalization." Cultural Anthropology 28, no. 2: 278-98. http://dx.doi.org/10.1111/cuan.12004.

Ghertner, D. Asher

2011 "Rule by Aesthetics: World-Class City Making in Delhi." In Worlding Cities: Asian Experiments and the Art of Being Global, edited by Ananya Roy and Aihwa Ong,

Graeber, David 279-306. Malden, Mass.: Wiley-Blackwell.

2005 "Fetishism as Social Creativity, or Fetishes are Gods in the Process of Construction.” Anthropological Theory 5, no. 4: 407-38. http://dx.doi.org/ $10.1177 / 1463499605059230$.

Gupta, Akhil

2012 Red Tape: Bureaucracy, Structural Violence, and Poverty in India. Durham, N.C.: Duke University Press. 
Heidegger, Martin

1971 “The Thing." In Poetry, Language, Thought, edited and translated by Albert Hofstadter, 165-82. New York: Harper \& Row.

Herzfeld, Michael

1992 The Social Production of Indifference: Exploring the Symbolic Roots of Western Bureaucracy. Chicago: University of Chicago Press.

2009 "The Cultural Politics of Gesture: Reflections on the Embodiment of Ethnographic Practice.” Ethnography 10, no. 2: 131-52. http://dx.doi.org/ $10.1177 / 1466138109106299$.

Hetherington, Kregg

2011 Guerrilla Auditors: The Politics of Transparency in Neoliberal Paraguay. Durham, N.C.: Duke University Press.

Holmes, Douglas R., and George E. Marcus

2005 "Cultures of Expertise and the Management of Globalization: Toward a Refunctioning of Ethnography." In Global Assemblages: Technology, Politics, and Ethics as Anthropological Problems, edited by Aihwa Ong and Stephen J. Collier, 235-62. Malden, Mass.: Blackwell.

Holston, James

1991 "The Misrule of Law: Land and Usurpation in Brazil." Comparative Studies in Society and History 33, no. 4: 695-725. http://dx.doi.org/10.1017/ S0010417500017291.

Hull, Matthew S.

2012a "Documents and Bureaucracy." Annual Review of Anthropology 41: 251-67. http://dx.doi.org/10.1146/annurev.anthro.012809.104953.

2012b Government of Paper: The Materiality of Bureaucracy in Urban Pakistan. Berkeley: University of California Press.

Ingold, Tim

2012 “Toward an Ecology of Materials.” Annual Review of Anthropology 41: 427-42. http://dx.doi.org/10.1146/annurev-anthro-081309-145920.

Larkin, Brian

2013 “The Politics and Poetics of Infrastructure." Annual Review of Anthropology 42: 327-43. http://dx.doi.org/10.1146/annurev-anthro-092412-155522.

Mathews, Andrew S.

2011 Instituting Nature: Authority, Expertise, and Power in Mexican Forests. Cambridge, Mass.: MIT Press.

Miller, Daniel

2005 "Materiality: An Introduction." In Materiality, edited by Daniel Miller, 1-50. Durham, N.C.: Duke University Press.

Nakassis, Constantine V.

2013 “Materiality, Materialization.” HAU: Journal of Ethnographic Theory 3, no. 3: 399406. http://dx.doi.org/10.14318/hau3.3.022.

Navaro-Yashin, Yael

2007 "Make-Believe Papers, Legal Forms, and the Counterfeit: Affective Interactions between Documents and People in Britain and Cyprus." Anthropological Theory 7, no. 1: 79-98. http://dx.doi.org/10.1177/1463499607074294.

Ong, Aihwa

2004 “The Chinese Axis: Zoning Technologies and Variegated Sovereignty.” Journal of Richland, Justin B.

East Asian Studies 4, no. 1: 69-96. http://www.jstor.org/stable/23417963.

2013 "Jurisdiction: Grounding Law in Language." Annual Review of Anthropology 42: 209-26. http://dx.doi.org/10.1146/annurev-anthro-092412-155526.

Rico, Laura

2010 "La nueva torre de Unicentro: Una pelea con los vecinos y con el Distrito." La Silla Vacía, August 14. http://lasillavacia.com/historia/17364. 
Riles, Annelise

2005 “A New Agenda for the Cultural Study of Law: Taking on the Technicalities." Buffalo Law Review 53: 973-1033.

Riles, Annelise, ed.

2006 Documents: Artifacts of Modern Knowledge. Ann Arbor: University of Michigan Press. Roy, Ananya

2009 "Why India Cannot Plan Its Cities: Informality, Insurgence, and the Idiom of Urbanization.” Planning Theory 8, no. 1: 76-87. http://dx.doi.org/10.1177/ 1473095208099299.

Salazar Ferro, José

2007 "La planeación de Bogotá: Un sistema híbrido de desarrollo progresivo." Revista Bitácora Urbano Territorial 11: 208-19. http://www.redalyc.org/articulo.oa? id $=74811112$.

Schwenkel, Christina

2015 "Reclaiming Rights to the Socialist City: Bureaucratic Artefacts and the Affective Appeal of Petitions." South East Asia Research 23, no. 2: 205-25. http://

Silva, Sónia dx.doi.org/10.5367/sear.2015.0257.

2013 "Reification and Fetishism: Processes of Transformation." Theory, Culture \& Society 30, no. 1: 79-98. http://dx.doi.org/10.1177/0263276412452892.

Star, Susan Leigh

2002 "Infrastructure and Ethnographic Practice: Working on the Fringes." Scandinavian Journal of Information Systems 14, no. 2: 107-22. http://aisel.aisnet.org/sjis/ vol14/iss2/6.

Taussig, Michael

1992 The Nervous System. New York: Routledge.

Tomlins, Christopher, and John Comaroff

2011 “Law as . . .': Theory and Practice in Legal History." UC Irvine Law Review 1, no. 3: 1039-79. http://scholarship.law.uci.edu/ucilr/vol1/iss3/.

Valverde, Mariana

2012 Everyday Law on the Street: City Governance in an Age of Diversity. Chicago: University of Chicago Press. 